\title{
A research on a new structure of forming tool in Single Point Incremental Forming (SPIF)
}

\author{
Le Khanh Dien ${ }^{1, *}$, Nguyen Van Thanh ${ }^{2}$, Nguyen Tan Hung ${ }^{2}$
}

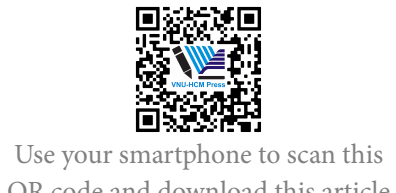

QR code and download this article

\begin{abstract}
Single Point Incremental Forming (SPIF) is really a new technology of forming metal sheet nowadays and in recent decades. Although it was invented in, 1967 by Lezak, an American inventor, but the applications of the innovative technology were broad from 1990 because of the advance of controlling technology. This technology is especially adapted to small batch, unique or single productions. There are many forming parameters that influence to the formability of the metal sheet workpiece such as diameter of tool, the revolution per minute of the tool tip, the vertical feed rate after each orbit, the velocity of tool in horizontal plane.... Among of them, in our own experiences, we recognize that in almost all cases, the revolution per minute of the forming tool when forming ferric material sheet such as mild steel, stainless steel, hard steels... should be as small as possible to get the biggest ability of deformation of the workpiece sheet to get rid of failure on the lateral edge of the sheet. The tangential velocity of forming point on the spherical tool tip should be selected to attain the situation of rolling but no sliding of the surface of the spherical tool on the one of the sheet material. The paper recommends a new version of a forming tool in which the tip of the tool is a very hard ball (such as the quenched ball in a ball bearing) that is freely rotate by the friction to modify the contact point on the spherical surface of the tool to avoid the abrading and keep the spherical shape and the situation of rotating but no sliding on the surface of the workpiece sheet as mentioned above. The manufacture of the innovative forming tool is performed and then empirical processes verified it. The models formed by the typical tool are better in comparison with the ones of normal forming tool.
\end{abstract}

Key words: SPIF, stresses, strains, deformation, pestle, forming tool, quenched ball, axle

${ }^{1}$ Ho Chi Minh City University of Technology (HCMUT), Vietnam

${ }^{2}$ DCSELAB - Ho Chi Minh City University of Technology, VNUHCM, Vietnam

Correspondence

Le Khanh Dien, Ho Chi Minh City University of Technology (HCMUT), Vietnam

Email: lyquingtien@gmail.com

History

- Received: 17-10-2018

- Accepted: 14-12-2018

- Published: 31-12-2019

DOI : 10.32508/stdjet.v3iSI1.757

\section{Check for updates}

\section{Copyright}

(c) VNU-HCM Press. This is an openaccess article distributed under the terms of the Creative Commons Attribution 4.0 International license.

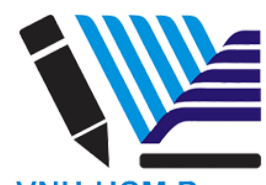

VNU-HCM Press

\section{INTRODUCTION}

According to almost all researches, ${ }^{1-3}$ the forming mechanics in Incremental Sheet Forming (ISF) differs from conventional forming process as the material is mainly deformed by local deformation at contact area between tool and workpiece sheet. Due to the forming mechanism of the Forming Limit Curve (FLC) Figure 4 in ISF is higher than the one in conventional processes, and typically defined by a negative slope straight line. During the forming process the sheet suffers a combination of shear, stretching and bending that lead to thinning, approximated by the sin law: $\mathrm{t}_{f}=\mathrm{t}_{0} \times \sin (90-\phi)$. Figures 3 and 4 The failure conditions in SPIF mostly occur with uniform thinning until fracture. Failure results on cracking that typically fallows a zigzag propagation. Aside from fracture, failure may include skinning ${ }^{4}$, essentially when dealing with larger forming forces ${ }^{1}$. The purpose of this paper is a recommendation of way of enhancing the formability of the Single Point Incremental Forming (SPIF) by a new structure of tool and spindle to eliminate or to decrease the friction between tool and workpiece sheet.

\section{METHOD: SCHEME OF RECOMMENDATION A NEW STRUCTURE OF SPIF TOOL AND RESULT}

Normally a traditional ISF tool is hold via a suitable collet in the spindle of CNC milling or specialize ISF machine as in Figure 1. It rotates with the RPM of the spindle that is selected with a suitable value according to the sheet material, coarse or finishing session.

Because tool have no cutting edge so we do not known the effect of its rotation on the ability of forming metal sheet. We carried out an experiment on 3 typical materials sheets:

- Aluminum A 1059 H14 stands for nonferrous metal,

- SS330 steel stands for popular mild steel,

- SUS304 stainless steel stands for popular metal used in industry and daily life.

In order to evaluate the effect of revolution of the tool when forming sheet by SPIF technology, a set of 4 in- 


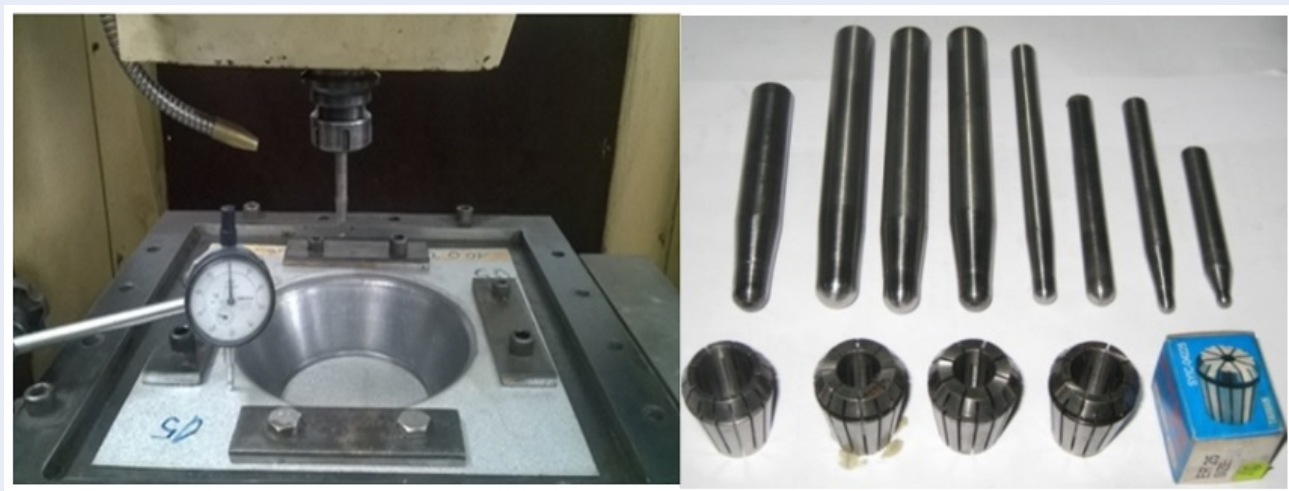

Figure 1: Traditional tool in finishing session (National Key Laboratory of Digital Control and System EngineeringDCSELAB)

Table 1: Initial limited values of $\mathbf{4}$ parameters

\begin{tabular}{lllll}
\hline A 1050-H14 (sheet width $\mathrm{t}=1 \mathrm{~mm})$ & & & \\
Values & $\triangle \mathrm{z}(\mathrm{mm})$ & $\mathrm{D}(\mathrm{mm})$ & $\mathrm{Vxy}(\mathrm{mm} /$ minute $)$ & $\mathrm{n}(\mathrm{RPM})$ \\
Min & 0.2 & 5 & 800 & 400 \\
Max & 1 & 10 & 3000 & 2500 \\
SS330 (sheet width $\mathrm{t}=0.6 \mathrm{~mm})$ & & & \\
Values & $\triangle \mathrm{z}(\mathrm{mm})$ & $\mathrm{D}(\mathrm{mm})$ & $\mathrm{Vxy}(\mathrm{mm} /$ minute $)$ & $\mathrm{n}(\mathrm{RPM})$ \\
Min & 0.2 & 5 & 800 & 400 \\
Max & 1 & 10 & 3000 & 2000 \\
SUS304 (sheet width $\mathrm{t}=0.4 \mathrm{~mm})$ & & & $\mathrm{n}(\mathrm{RPM})$ \\
Values & $\triangle \mathrm{z}(\mathrm{mm})$ & $\mathrm{D}(\mathrm{mm})$ & $\mathrm{Vxy}(\mathrm{mm} /$ minute $)$ & 400 \\
Min & 0.2 & 5 & 800 & 800 \\
Max & 1 & 10 & 3000 & \\
\hline
\end{tabular}

fluential parameters and suitable selected limited values are illustrated in Table 1, wherein:

- Depth rate Dz of tool after a round of orbit;

- Diameter of tool D (mm);

- Feed rate on horizontal plane Vxy (mm/minute);

- Revolution per minute of the tool $n$ (RPM).

In order to measure the angle a that makes of the tangent line with the sheet profile and the horizontal line at the first tore point on the sheet, a model profile is selected in Figure 2.

Herein: $\mathrm{R}$ radius of model profile, $\mathrm{z}$ depth at random point on profile. The angle $\alpha$ that stands for the formability ${ }^{2,4}$ is calculated by $\alpha=\operatorname{arc} \cos \left(\frac{R-z}{R}\right)$. All the experiments were achieved in Specialized SPIF machine (Figure 3) in CAD-CAM workshop of DCSELAB.

\section{Empirical process and result}

In the Design of Experiment (DOE), 2 limited values are used in partial DOF of 4 factors, so the number of experiments for each typical metal is $24-1=8$. Calculated number of iteration is 3 . Therefore, the number of models for each typical material is $8 \times 3=24$. The initial limited values of each parameter are selected according to the ability of machines and the stiffness of tool and metal sheet:

The average results of measuring the angle of deformation of 3 typical materials:

From the results of angle a that stand for the formability of 3 materials under the influence of 4 parameters in Table 2, with the help of Minitab software, we attempt to form 3 recursion equations of the angle of formability: 


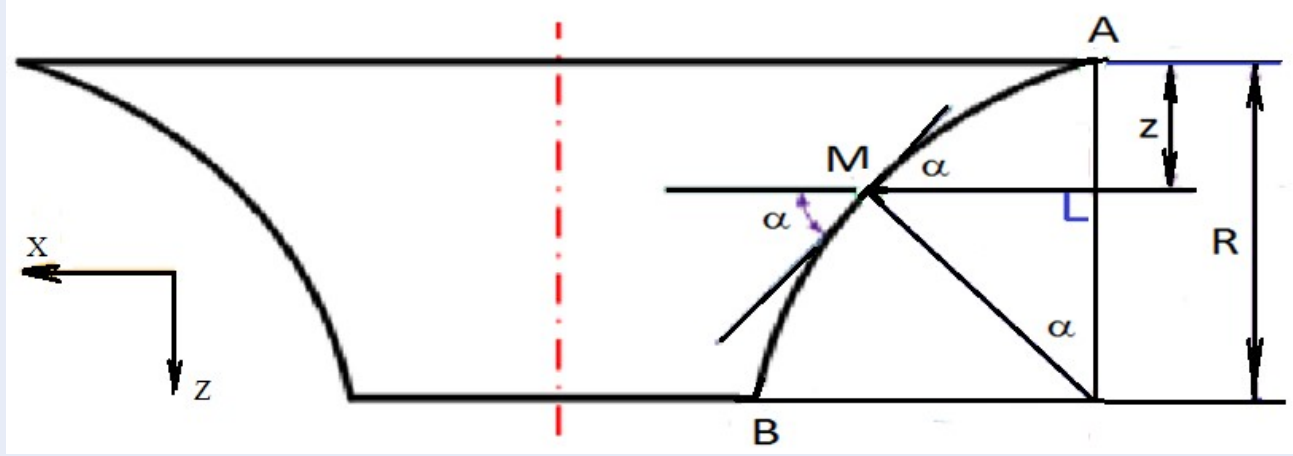

Figure 2: SPIF model used in experiment

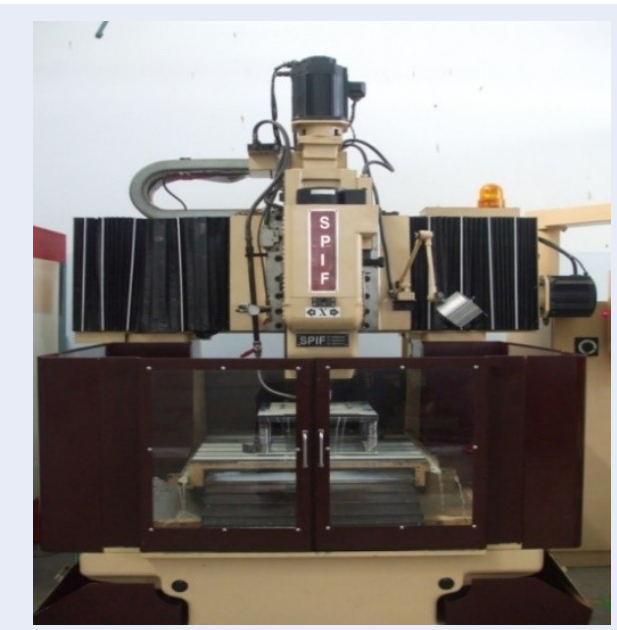

Figure 3: Specialized SPIF machine in CAD-CAM workshop of DCSELAB

Aluminum A 1050-H14:

$$
\begin{gathered}
\alpha=82.77-0.6 \triangle_{z}-0.757 D-0.001845 V_{x y} \\
+0.00023_{n}-0.33 D \triangle_{z}-0.00021 D V_{x y}
\end{gathered}
$$

The partial differential of $\mathrm{n}$ is derived from the above equation to define the influence of revolution $\mathrm{n}$ to $\alpha$ $\frac{\partial \alpha}{\partial n}=0.00023>0$

Hence, in case of aluminum or other nonferrous metal, the formability is covariant with the revolution of the tool. We can say that the higher the revolution of the tool, the bigger the formability of the product. Recursion equation of mild steel SS330:

$$
\begin{gathered}
\alpha=70.38-0.78 \triangle_{z}-0.317 D-0.001 n \\
-0.417 \triangle_{z} D+0.002 \triangle_{z} V_{x y} \\
\frac{\partial \alpha}{\partial n}=-0.001<0
\end{gathered}
$$

Recursion equation of stainless steel SUS304: $\alpha=63.10-18.163 \triangle_{z}-D-0.0008 V_{x y}$

$$
\frac{\partial \alpha}{\partial n}=-0.0092<0
$$

From (1) and (2) we recognize that the formability of mild steel and stainless steel or more generality other ferrous metal is contra-variant with the revolution of the tool $\mathbf{n}$. That means that when forming the popular ferrous metal technician should select the value of revolution of spindle or tool as small as possible.

\section{Recommendation a new structure of SPIF tool for ferrous metal sheet}

Figure 4 illustrates the structure of SPIF tool that is designed for ferrous metal sheet only under our own experience in forming sheet by SPIF technology with following specifications:

- The thermal treated ball tip with the diameter of $\varnothing 5$ get the hardness of 60-62 HRC that is assembled on the end of the taper HSS body by cooper braze weld.

- HSS cylinder tool body with diameter of $\varnothing 12$ is hold with a couple of angular ball bearing Koyo 6000 via diameter of $\varnothing 10 \mathrm{~m}^{7}$

- The angular ball bearing are fixed inside a bushing which has outside diameter of $\varnothing 36$

- The bushing is hold by DIN 6388 collet OZ-32 ${ }^{5}$ inside the arbor of the spindle that illustrated in Figure 5

The structure of designed SPIF tool is represented in Figure 4. This innovative SPIF tool consists of a couple of thrust angular bearing and a shoulder of $\varnothing 44$ that could support the huge axial force that the workpiece sheet applies on the tool. With the selected bore of $\varnothing 32$, the designed tool could be perfectly held by standard OR-32 collet $^{5}$. 
Table 2: Results of doe for $\mathbf{3}$ typical materials

\begin{tabular}{|c|c|c|c|c|c|}
\hline \multicolumn{6}{|c|}{ A $1050-\mathrm{H} 14$} \\
\hline $\mathrm{N}_{0}$ & $\triangle \mathrm{z}(\mathrm{mm})$ & $\mathrm{D}(\mathrm{mm})$ & Vxy (mm/ minute) & $\mathrm{n}(\mathrm{RPM})$ & Average forming angle $\alpha\left({ }^{0}\right)$ \\
\hline 1 & 0.2 & 5 & 800 & 400 & 78.30 \\
\hline 2 & 1 & 5 & 800 & 2500 & 77.81 \\
\hline 3 & 0.2 & 10 & 800 & 2500 & 75.51 \\
\hline 4 & 1 & 10 & 800 & 400 & 72.72 \\
\hline 5 & 0.2 & 5 & 3000 & 2500 & 76.89 \\
\hline 6 & 1 & 5 & 3000 & 400 & 75.73 \\
\hline 7 & 0.2 & 10 & 3000 & 400 & 75.45 \\
\hline 8 & 1 & 10 & 3000 & 2500 & 73.91 \\
\hline \multicolumn{6}{|c|}{ SS330 } \\
\hline $\mathrm{N}_{0}$ & $\triangle \mathrm{z}(\mathrm{mm})$ & $\mathrm{D}(\mathrm{mm})$ & Vxy $(\mathrm{mm} /$ minute $)$ & $\mathrm{n}(\mathrm{RPM})$ & Average forming angle $\alpha\left({ }^{0}\right)$ \\
\hline 1 & 1 & 5 & 800 & 2000 & 73.7 \\
\hline 2 & 0.2 & 5 & 800 & 400 & 76.4 \\
\hline 3 & 1 & 10 & 800 & 400 & 66.5 \\
\hline 4 & 0.2 & 10 & 800 & 2000 & 69.1 \\
\hline 5 & 1 & 5 & 3000 & 400 & 73.3 \\
\hline 6 & 0.2 & 5 & 3000 & 2000 & 77.8 \\
\hline 7 & 1 & 10 & 3000 & 2000 & 68.3 \\
\hline 8 & 0.2 & 10 & 3000 & 400 & 78.5 \\
\hline \multicolumn{6}{|c|}{ SUS304 } \\
\hline $\mathrm{N}_{0}$ & $\triangle \mathrm{z}(\mathrm{mm})$ & $\mathrm{D}(\mathrm{mm})$ & Vxy $(\mathrm{mm} /$ minute $)$ & $\mathrm{n}(\mathrm{RPM})$ & Average forming angle $\alpha\left({ }^{0}\right)$ \\
\hline 1 & 1 & 5 & 800 & 800 & 65.36 \\
\hline 2 & 0.2 & 5 & 800 & 400 & 66.41 \\
\hline 3 & 1 & 10 & 800 & 400 & 62.44 \\
\hline 4 & 0.2 & 10 & 800 & 800 & 63.68 \\
\hline 5 & 1 & 5 & 3000 & 400 & 63.41 \\
\hline 6 & 0.2 & 5 & 3000 & 800 & 66.27 \\
\hline 7 & 1 & 10 & 3000 & 800 & 65.84 \\
\hline 8 & 0.2 & 10 & 3000 & 400 & 64.15 \\
\hline
\end{tabular}




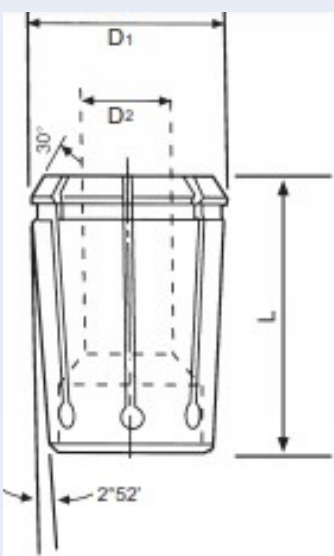

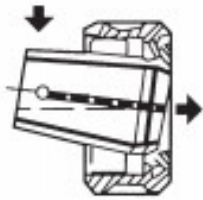

A

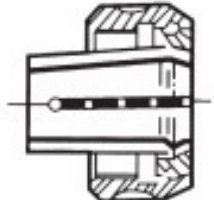

B

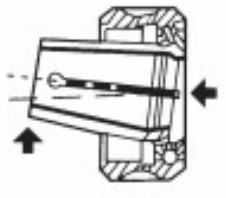

C

\section{METRIC}

\begin{tabular}{|c|c|c|c|}
\hline $\begin{array}{c}\text { ORDER } \\
\text { NO. }\end{array}$ & D1 & L & D 2 (MM) \\
\hline OZ-16- $\square$ & 25.5 & 40 & $2,3,4,5,6,7,8,9,10,11,12,13,14,15,16$ \\
\hline OZ-25- $\square$ & 35.05 & 52 & $3,4,5,6,7,8,9,10,11,12,13,14,15,16,18,20,25$ \\
\hline OZ-32- $\square$ & 44 & 60 & $6,8,10,12,16,20,25,32$ \\
\hline
\end{tabular}

Figure 5: Parameters of selected bushing OZ-32 for holding tool ${ }^{5}$.

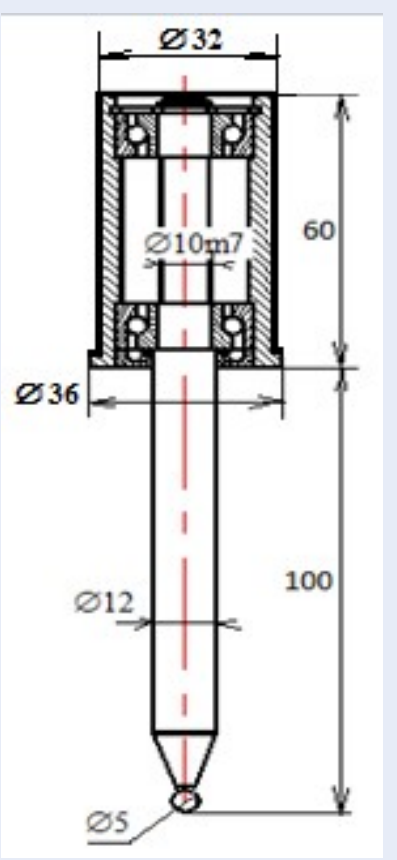

Figure 4: Structure of the designed SPIF tool
Result of the new structure of SPIF tool for ferrous metal sheet

The application of the new structure of the tool for popular mild steel is useful to increase the formability of these ferous sheet materials as in Figure 6.

\section{DICUSSION}

The innovative structure of SPIF tool could be directly assembled to the arbor of the 3D CNC milling machine or the current specialist 3D ISF machine in DCSELAN. In the future, when the effective performance of the new designed tool will be proved, it could be assembled to a future structure head tool that will reach the convertible modification to 5D CNC ISF machine.

\section{CONCLUSION}

This design tool is applied on y for ferrous sheet. In operation, the spindle of CNC milling machine or specialized SPIF machine have to be set fixed and stable. Because of the friction between the spherical tool tip and the sheet material, the ball rotates no sliding on the surface of the formed sheet to get the smallest revolution to satisfy the condition to enhance the formability of almost all ferrous material sheets. 


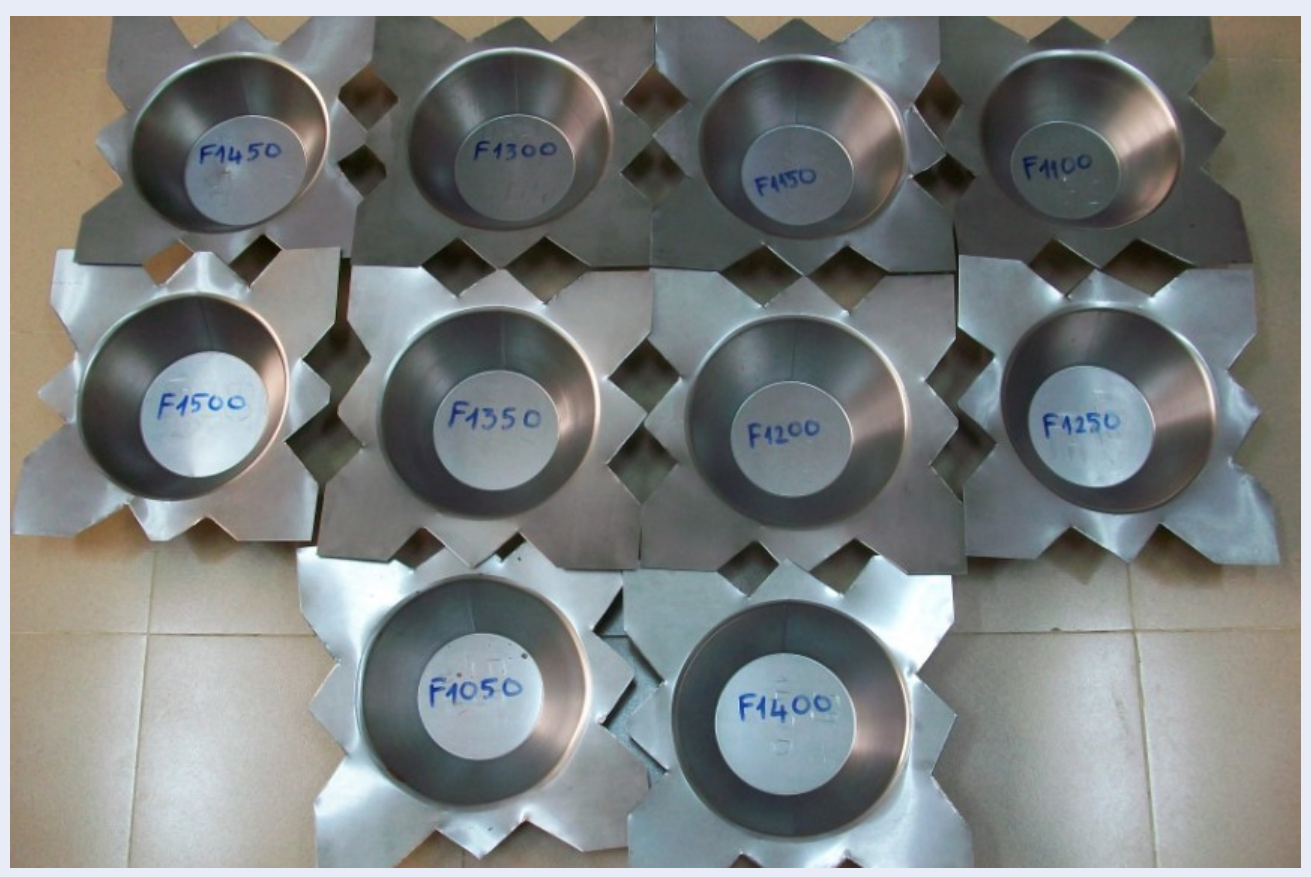

Figure 6: Better result on SS300 ferous models after the application of the innovation of new structure of forming tool

\section{ACKNOWLEDGEMENTS}

This research is supported by DCSELAB and funded by Viet Nam National University Ho Chi Minh City (VNUHCM) under grant number TX2018-20b-01. We appreciate highly the great support of the board of DCSELAB that gave us the opportunity to perform this research.

\section{LIST OF ABBREVIATIONS :}

SPIF : Single Point Incremental Forming ISF: Incremental Sheet Forming

FLC: Forming Limit Curve

CNC: Computer Numerical Control

DOE: Design of Experiments

HSS: High Speed Steel

HRC: Hardness Rockwell C

DIN: Deutsches Institut für Normung

\section{CONFLICT OF INTEREST}

The authors declare that there is no conflict of interest regarding the publication of this article.

\section{AUTHOR'S CONTRIBUTION}

Le Khanh Dien: (50\%) Abstract, Introduction, Method and Result

Nguyen Van Thanh: (25\%) Discussion

Nguyen Tan Hung: (25\%) Conclusion

\section{REFERENCES}

1. Afonso $D$, Sousab RA, Torcato R. Incremental forming of tunnel type parts. ScienceDirect Elsevier. 2017;183:137-142. Available from: https://doi.org/10.1016/j.proeng.2017.04.036.

2. Jackson K, Allwood J. The mechanics of incremental sheet forming. Journal of Materials Processing Technology. 2009;209(3):1158-1174. Available from: https://doi.org/10. 1016/j.jmatprotec.2008.03.025.

3. Ham M, Jeswiet J. Forming Limit Curves in Single Point Incremental Forming. CIRP Annals Manuf Tech. 2007;56(1):277-280. Available from: https://doi.org/10.1016/j.cirp.2007.05.064.

4. Sousa RJA, Ferreira JAF, Farias JBS, Torrão JND, Afonso DG, Martins MABE. SPIF-A: on the development of a new concept of incremental forming machine. Structural Engineering and Mechanics. 2014;49(5):645-660. Available from: https://doi.org/10. 12989/sem.2014.49.5.645.

5. VERTEX. DIN 6388 Collet for Milling Chuck; 


\title{
Nghiên cứu thiết kê kết cấu mới của dụng cụ tạo hình trong công nghệ tạo hình tấm bằng biến dạng đơn điểm
}

\author{
Lê Khánh Điền ${ }^{1, *}$, Nguyễn Văn Thạnh ${ }^{2}$, Nguyễn Tấn Hùng²
}

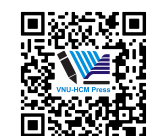

Use your smartphone to scan this QR code and download this article

\begin{abstract}
TÓM TÁ́T
Công nghệ tạo hình tấm đơn điểm (SPIF) thực sự là một công nghệ tạo hình tấm kim loại mới ngày nay và trong những thập niên gần đây. Mặc dù công nghệ này được phát minh vào năm 1967 do Lezak, một nhà phát minh người Mỹ, nhưng các ứng dụng của công nghệ này mới được mở rộng từ năm 1990 do sự tiến bộ của công nghệ điều khiền. SPIF đặc biệt thích ứng với các mô hình sản lượng nhỏ, sản phẩm độc đáo hoặc đơn chiết. Có nhiều thông số hình thành ảnh hưởng đến khả năng tạo hình của tấm kim loại như đường kính dụng cụ, tốc độ quay của đầu dụng cụ, lượng tiến dunng cư xuống sau mỗi quỹ đạo, vận tốc của dung cụ trong mặt phẳng ngang... Trong số đó, theo kinh nghiệm chúng tôi nhận ra rằng trong hầu hết các trường hợp, tốc độ quay của dụng cụ tạo hình khi tạo thành tấm vật liệu nên sắt như thép mềm, thép không gỉ, thép cứng nên càng nhỏ càng tốt để có được khả năng biến dạng lớn nhất của tấm phôi mà không làm rách tấm kim loại. Vận tốc tiếp tuyến của điểm hình thành trên đầu dụng cụ hình cầu nên được chọn để đạt được tình trạng lăn nhưng không trượt trên bể mặt của tấm. Bài báo đê xuất một kết cấu mới của công cụ tạo hình, trong đó đầu của dụng cụ là một viên bi rất cứng (như viên bi trong ổ bi) được xoay tự do bằng ma sát với bề mặt tấm nhằm thay đổi điểm tiếp xúc trên bê mặt hình cầu của công cụ để tránh mài mòn và giữ hình dạng hình cầu đáp ứng tình trạng quay khồng trượt trên bề mặt của tấm phôi như đã đề cập ở trên. Việc chế tạo và lắp ráp dụng cụ tạo hình mới được thực hiện và các ứng dụng thực nghiệm đã được thực hiện cho thấy các mẫu được hình thành bởi công cụ điển hình khả quan và tốt hơn so với các mẫu do các dụng cụ thông thường tạo hình.
\end{abstract}

Từ khoá: Công nghệ tạo hình tấm đơn điểm, ứng suất, biến dạng, Sự biến dạng, chày, Dụng cụ tạo hình, Bi được nhiệt luyện, Trục

\begin{abstract}
${ }^{I}$ Trường Đại học Bách khoa (HCMUT), ĐHQG-HCM, Việt Nam

${ }^{2}$ Phòng Thí nghiệm Trọng điểm Quốc gia (DCSELAB), HCMUT, ĐHQG-HCM,

Việt Nam

Liên hệ
\end{abstract}

Lê Khánh Điền, Trường Đại học Bách khoa (HCMUT), ĐHQG-HCM, Việt Nam

Email: lyquingtien@gmail.com

Lịch sử

- Ngày nhận: 17-10-2018

- Ngày chấp nhận: 14-12-2018

- Ngày đăng: 31-12-2019

DOI : 10.32508/stdjet.v3iSI1.757

\section{Check for updates}

\section{Bản quyền}

๑ Đ ĐHQG Tp.HCM. Đây là bài báo công bố mở được phát hành theo các điều khoản của the Creative Commons Attribution 4.0 International license.

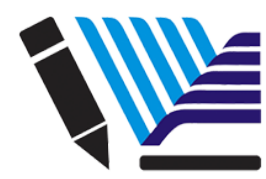

VNU-HCM Press
Trích dẫn bài báo này: Điền $L K$, Thạnh $N \mathrm{~V}$, Hùng $\mathrm{N} T$. Nghiên cứu thiết kê kết cấu mới của dụng cụ tạo hình trong công nghệ tạo hình tấm bằng biến dạng đơn điểm. Sci. Tech. Dev. J. - Eng. Tech.; 2(SI1):SI157-SI163. 